\title{
THE EFFECT OF SHIFTING WEALTH OWNERSHIP ON THE TERM STRUCTURE OF INTEREST RATES: THE CASE OF PENSIONS*
}

\author{
BENJAMIN M. FRIEDMAN
}

Substantial shifts in wealth ownership from individuals to pension funds are currently taking place in the United States and also are in prospect for the foreseeable future. Moreover, pension funds typically exhibit portfolio preferences that are markedly different from those of individuals. In a world of heterogeneous investors, redistributions among wealth holders with different portfolio preferences will in general alter the structure of asset yields. Partial-equilibrium simulation experiments based on a model of the U.S. long-term bond market indicate that redistributions of saving flows from individuals to pension funds, in plausible magnitudes, can have major effects on the term structure of interest rates.

In a world in which wealth holders' risk aversion renders different assets less than perfect substitutes, the interaction between investors' portfolio preferences and existing asset supplies determines the structure of asset yields. Using a model in which the only explicitly traded assets are money and bonds, for example, Patinkin [1965] showed explicitly how either a shift in the exogenously determined outside stocks of these two assets (i.e., an open market operation) or an exogenous shift in wealth holders' liquidity preference changes "the interest rate." Similarly, using a more general model in which the relevant assets include money, short-term debt securities, and longterm capital (equity), Tobin [1969] showed how both short- and long-term yields depend again on the system's asset demand functions and on the exogenous outside asset supplies.

Following the appearance of Tobin's [1963] classic "Essay on the Principles of Debt Management," there was for some time considerable public policy interest in exploiting these means of shifting the prevailing asset yield relationships. The "Operation Twist" experiment during 1961-1964 attempted to reduce long- relative to shortterm yields by a surrogate debt management operation in which the Federal Reserve System deliberately increased the amounts of longrelative to short-term securities held in the portfolio of the System

* The author is grateful to Vance Roley for research assistance; to James Duesenberry, Martin Feldstein, Laura Lee Matthews, Franco Modigliani, Heraklis Polemarchakis, Irwin Tepper, James Tobin, and especially John Lintner and Vance Roley, for helpful discussions and comments on previous drafts of this paper; and to the National Science Foundation (Grants SOC 74-21027 and APR 77-14160), the Alfred P. Sloan Foundation, and the National Bureau of Economic Research for research support. 
Open Market Account. While the average slope of the yield curve did flatten during this period, most subsequent empirical analyses associated this observed phenomenon with moderating expectations for short-term yields in the future and hence discounted the role of the Federal Reserve's policy actions in directly causing it. ${ }^{1}$ Interest in active debt management policy, among both economists and policy makers, has waned considerably since that time.

Although asset supplies constitute only one-half of the determination of the structure of asset yields, the prevailing methodology of economists' empirical analyses has effectively precluded introducing into research on yield relationships any explicit consideration of the other half-i.e., the role of wealth holders' portfolio preferences as in Patinkin's theoretical discussion. In order to contribute to a shift in the structure of asset yields, some aspect of liquidity preference must itself shift. By working with aggregate asset demand functions or their derivative reduced forms (thereby assuming that all wealth holders are homogeneous), and moreover by holding these functions fixed throughout the analysis (thereby assuming that the homogeneous wealth holders' behavior remains unchanged), researchers have typically used models that leave shifting asset supplies as the only possible engine for bringing about shifting yield relationships. ${ }^{2}$

This paper examines the question of relative asset yield determination from the opposite perspective-explicitly considering the effect of a shift in the economy's aggregate portfolio preferences, while holding outside asset supplies fixed. The key to this analysis is to relax the standard assumption that all wealth holders are homogeneous, since in fact different groups of investors typically display sharply distinct asset preferences. In order to delineate explicitly the differences in behavior among heterogeneous groups of wealth holders, it is useful to work directly with the relevant asset demand relationships rather than with reduced-form systems. The device that then produces a shift in the economy's aggregate portfolio preferences is a shift in the pattern of wealth ownership among the heterogeneous groups. Since major shifts of this kind not only are currently taking place in the United States but will be even more pronounced in the future because of recent pension legislation, not to mention a variety of

1. See, for example, Modigliani and Sutch [1966, 1967]. Moreover, because the Treasury was emphasizing long-term issues at this time, in fact the average maturity of the outstanding U. S. government debt rose modestly during these years; see Friedman [1978].

2. Bosworth and Duesenberry [1973] and Hendershott [1977] were exceptional in this regard, in that they worked with disaggregated models, but they did not use their models to analyze the effects of shifting patterns of wealth ownership. 
further pension reform proposals, ${ }^{3}$ the real-world relevance of such considerations for the determination of asset yields is at least as great as that of any possible shifts in outside asset supplies. Appropriately or not, for practical applications debt management policy seems for the present to be a dead horse ${ }^{4}$ by contrast, shifts in the pattern of wealth holding-together with associated shifts in aggregate portfolio preferences-are a very live issue for the present and foreseeable future.

Section I briefly illustrates the role in the determination of asset yields of shifting aggregate portfolio preferences due to shifting wealth ownership, using for this purpose a financial sector model analogous to Tobin's [1969] but disaggregated to reflect (for simplicity, in this abstract discussion) two distinct groups of wealth holders. As in Tobin's model, the analysis here and in the remainder of this paper is partial equilibrium in character, in that it does not incorporate short-run feedbacks from the nonfinancial to the financial sector. ${ }^{5}$ Section II focuses on the distinct asset demand preferences exhibited by individuals' directly held portfolios and pension funds' portfolios in the United States, drawing in part on empirical evidence on these investors' demands for long-term bonds provided by the demand functions estimated in Friedman [1977]. Section III uses partialequilibrium, market-clearing simulation experiments based on these estimated bond demand functions (and two analogous bond supply equations) to evaluate the likely term-structure effects of specific shifts in the form of wealth ownership from individuals' direct holdings to pension funds. According to a priori judgments of these investors' portfolio preferences, supported by the estimated asset demand functions, wealth ownership shifts in this direction reduce aggregate liquidity preference. To anticipate, the experiments' results indicate that such shifts, in plausible magnitudes, would lead to substantial reductions in long-term bond yields for given short-term yields-i.e., they would reduce the average slope of the term-structure yield curve. Section IV briefly summarizes the paper's principal conclusions.

3. See, for example, Feldstein [1976] and Munnell and Connolly [1976]. See Friedman [1976] for a specific discussion of the asset market implications of these authors' proposals along the lines argued in this paper.

4. Examples of recent interest in debt management policy, however, include Friedman [1978] and Roley [1979].

5. By arguing that over time investment is a positive function of the ratio of market price to replacement cost for capital goods, Tobin did sketch the extension of his model to full general equilibrium; the bulk of his analysis, however, was a partial-equilibrium treatment of the asset markets. 


\section{PORTFOLIO Allocation AND EQUILIBRIUM YiELDS WiTH HETEROGENEOUS INVESTORS}

Correctly specified asset demand functions presumably reflect the expected-utility-maximizing behavior of individual, risk-averse investors choosing optimal portfolio allocations, in a world of uncertainty, subject to various constraints. ${ }^{6}$ Because the theory of expected utility maximization in its full generality does not yield asset demand functions that are tractable for most analytical or empirical purposes, however, it is necessary to impose simplifying assumptions. Two particular assumptions, both of which are commonplace in the vast literature of expected-utility-maximizing portfolio behavior, provide a convenient beginning here. First, as is standard in a wide variety of models, it is useful to abstract from interdependent decisions with respect to saving and portfolio allocation and to focus instead on the more limited problem of the allocation of existing portfolio wealth together with (as in Section II below) a given saving flow. ${ }^{7}$ Wholly apart from its analytical convenience, this assumption is especially appropriate for institutional investors like pension funds that have both their income and their outlays fixed by contractual and actuarial circumstances in at least the short and medium runs. Second, as has become virtually standard since the work of Markowitz [1952] and Tobin [1958], it is useful to restrict the class of representations of the investor's utility or beliefs or both to those that reduce to preference orderings in terms of the mean and variance of some specific result of the portfolio allocation (usually end-of-period wealth). ${ }^{8}$

Utility functions exhibiting constant relative risk aversion, together with joint normal (or lognormal) asset return distributions, generate optimal single-period portfolio allocations of the convenient

6. For a discussion of the usefulness of the expected-utility framework for analyzing decision making under uncertainty, see, for example, Arrow [1970]; Arrow's discussion also shows why risk aversion must be predominant in the aggregate.

7. For an example of the complications that arise when saving and portfolio allocation decisions are interdependent with some generality, see Merton [1969] and Samuelson [1969]. A large literature has also investigated the conditions (e.g., constant relative risk aversion) which, within the more general expected-utility-maximization framework, render multiperiod behavior in this context "myopic" and hence analytically equivalent to single-period behavior; see, for example, Mossin [1968] and Fama [1970].

8. Numerous researchers have criticized various aspects of mean-variance analysis see, in particular, Hicks [1962], Lintner [1965], Borch [1969], Feldstein [1969], and Arrow [1970]. As both Markowitz and Tobin originally emphasized, however, the justification for the mean-variance framework is not its precise and universal validity but rather its appeal as a tractable approximation useful for a variety of practical analytical purposes. Samuelson [1970] and Tsiang [1972] have subsequently provided theorems further strengthening the argument for mean-variance analysis when the amount of risk involved is small relative to initial wealth. 
linear homogeneous form, ${ }^{9}$

$$
\boldsymbol{\alpha}_{t}^{*} \equiv \frac{1}{W_{t}} \cdot \mathbf{A}_{t}=B_{t} \mathbf{r}_{t}^{e}+\pi_{t},
$$

where, for specific time, $t, W_{t}$ is total portfolio wealth, $\mathbf{A}_{t}$ is a vector of asset holdings $\left(\mathbf{A}_{t}^{\prime} 1=1\right), \mathbf{r}_{t}^{e}$ is a vector of the means of the corresponding perceived asset return distributions, and $B_{t}$ and $\pi_{t}$ are, respectively, a matrix and vector of coefficients determined by the utility function's coefficient of relative risk aversion $(\rho)$ and the variance-covariance matrix $\left(\Omega_{t}\right)$ of the perceived asset return distributions. ${ }^{10}$

If all wealth holders are homogeneous, then the optimal portfolio allocation (1), together with their aggregate wealth $W_{t}$, uniquely describes aggregate asset demands. For given exogenous aggregate supplies of outside assets (and with endogenous inside asset supplies treated simply as negative demands), general equilibrium in the asset markets is equivalent to the market-clearing condition,

$$
W_{t} \alpha_{t}^{*}-\mathbf{A}_{t}^{S}=\mathbf{0},
$$

where $\mathbf{A}_{t}^{S}$ is a vector of outside asset supplies at time $t$, and 0 is a vector with all zero elements. If the Jacobian $B_{t}$ is nonsingular, substitution from (1) then yields the determination of expected asset returns (and, consequently, actual beginning-of-period asset prices) according to

$$
\mathbf{r}_{t}^{e}=B_{t}^{-1}\left(\frac{1}{W_{t}} \mathbf{A}_{t}^{S}-\pi_{t}\right)
$$

The essence of "Operation Twist" and analogous debt management operations is to exploit this dependence of $\mathbf{r}_{t}^{e}$ on $\mathbf{A}_{t}^{S}$.

Now suppose that there exist two groups of homogeneous wealth holders with endowments $W_{1 t}$ and $W_{2 t}$, respectively, and characterized by different utilities such that the two relative risk aversion

9. Brainard and Tobin [1968] and the voluminous work following their lead have given numerous examples of the use of a linear homogeneous form in both abstract and empirical research, and M. Friedman [1956] and de Leeuw [1965] provided useful discussions of the homogeneity property in particular. Wholly apart from the attractiveness of the resulting asset demand functions, Friend and Blume [1975] offered empirical evidence supporting the assumption of constant relative risk aversion.

10. Specifically, if all assets are risky, $B_{t}=-1 / \rho\left[\Omega_{t}^{-1}-\left(1^{\prime} \Omega_{t}^{-1} 1\right)^{-1} \Omega_{t}^{-1} 11^{\prime} \Omega_{t}^{-1}\right]$ and $\pi_{t}=\left(1^{\prime} \Omega_{t}^{-1} 1\right)^{-1} \Omega_{t}^{-1} 1$. Here $B_{t}$ is singular, so that the asset demand system will be capable of determining all relative yields and all but one absolute yield. Alternatively, in the presence of a risk-free (i.e., certain return) asset, the full $\Omega_{t}$ matrix is singular, so that it is necessary to partition the set of demands; the resulting asset demand system, in which $\alpha_{t}^{*}, \mathbf{r}_{t}^{e}$ and $\Omega_{t}$ refer to the risky assets only, is then just $\alpha_{t}^{*}=B_{t} \mathbf{r}_{t}^{e}$, where $B_{t}=1 / \rho \Omega_{t}^{-1}$, and the optimal portfolio share for the risk-free asset is simply $\left(1-\alpha_{i}^{\prime} 1\right)$. See Roley [1977] for a thorough treatment of this distinction. 
coefficients differ by (with no loss of generality)

$$
\rho_{1}>\rho_{2}
$$

Further suppose that the two groups share identical information and hence identical assessments of asset return outcomes. Then the two groups' respective optimal portfolio allocations from (1) will differ so that, for given expected returns that yield interior solutions, group 2 will hold larger fractions of its total group wealth in the riskier assets than will group 1 . If there exist only one risky and one risk-free asset, for example, each group's desired relative holding of the risky asset will be

$$
\alpha_{R i t}^{*}=\frac{E\left(\tilde{r}_{R t}-r_{F t}\right)}{\rho_{i} V\left(\tilde{r}_{R t}-r_{F t}\right)}, \quad i=1,2,
$$

where $E(\cdot)$ denotes an expectation and $V(\cdot)$ a variance, and the subscripts $R$ and $F$ indicate the risky and risk-free assets, respectively.

Given the distinct behavior of the two groups of wealth holders, it is straightforward to show that shifts in wealth ownership in general affect relative asset yields. Instead of (2), the general equilibrium condition for the asset markets is now

$$
W_{1 t} \boldsymbol{\alpha}_{1 t}^{*}+W_{2 t} \boldsymbol{\alpha}_{2 t}^{*}-\mathbf{A}_{t}^{S}=\mathbf{0}
$$

so that substituting from the individual groups' asset demands analogous to (1) yields

$$
\mathbf{r}_{t}^{e}=\left(W_{1 t} B_{1 t}+W_{2 t} B_{2 t}\right)^{-1}\left(\mathbf{A}_{t}^{S}-W_{1 t} \pi_{1 t}-W_{2 t} \pi_{2 t}\right),
$$

where matrices $B_{1 t}$ and $B_{2 t}$ and vectors $\pi_{1 t}$ and $\pi_{2 t}$ again depend on the perceived variance-covariance structure. Hence the marketclearing vector of expected holding-period returns, for given total wealth $W_{t}$ (and given portfolio preferences, outside asset supplies, and variance assessments), varies according to the division of $W_{t}$ between the two groups of wealth holders as indicated by $W_{1 t}$ and $W_{2 t}$. Redistributing wealth ownership toward the less risk-averse investors (group 2), for example-i.e., increasing $W_{2 t}$ and correspondingly reducing $W_{1 t}$-reduces expected yields on the riskier assets relative to the safer assets.

It is also useful to consider explicitly the analogous implications of shifting wealth ownership on the market price of risk in the sense of Sharpe [1964] and Lintner [1965]. For the case of only one risky asset, for example-or, under an appropriate separation theorem that is valid given the assumptions underlying (1), a "market portfolio" of all the risky assets-substituting (5) into (6) yields 


$$
\frac{E\left(\tilde{r}_{R t}-r_{F t}\right)}{V\left(\tilde{r}_{R t}-r_{F t}\right)}=\frac{A_{R t}^{S}}{W_{t}}\left[\left(\frac{W_{1 t}}{W_{t}}\right) \frac{1}{\rho_{1}}+\left(\frac{W_{2 t}}{W_{t}}\right) \frac{1}{\rho_{2}}\right]^{-1}
$$

so that the slope of the Lintner-Sharpe capital market line depends in a straightforward way not only on the composition of the outside asset supplies $\left(A_{R t}^{S} / W_{t}\right.$ and $\left.\mathrm{A}_{F t}^{S} / W_{t}=1-A_{R t}^{S} / W_{t}\right)$ but also on the two investor groups' different behavior with respect to risk $\left(\rho_{1}\right.$ and $\left.\rho_{2}\right)$ weighted by their respective shares of wealth ownership $\left(W_{1 t} / W_{t}\right.$ and $\left.W_{2 t} / W_{t}=1-W_{1 t} / W_{t}\right)$. ${ }^{11}$ For given $W_{t}, \rho_{1}$, and $\rho_{2}$, therefore, it is possible to affect the equilibrium market risk-return relationship via either the composition of outside asset supplies (as in conventional debt management operations) or the distribution of asset holding. Redistributing wealth ownership toward the less risk-averse group 2 , for example, strictly reduces the market price of risk (i.e., lowers the capital market line's slope).

\section{Portfolio PREFERENCES OF HouseholdS AND PENSION FUNDS}

As is clear from the discussion in Section $I$, a change in the ownership of portfolio wealth in general affects market-clearing asset returns in a straightforward way. Does the same result follow for a change not in the ultimate ownership of wealth but rather in the institutional arrangements under which wealth is held? This question is relevant especially in the context of the substantial ongoing shift in U.S. private wealth ownership from direct holding by individuals to indirect holding via pension funds. In large part because of tax incentives both to workers and to private employers, in recent years pension funds have represented a rapidly growing share of U.S. private saving; and the Employee Retirement Income Security Act of 1974 has accelerated this process. ${ }^{12}$ Moreover, a variety of currently pending proposals would even further reinforce this shift toward saving via pensions.

Nevertheless, it is not obvious that the analysis of a change in who owns assets is analogous to a change in how the same people hold their assets. Pension funds, after all, are no more than intermediaries, and the ultimate owners of the assets held in pension funds are still the general public. Hence at one extreme, pension fund managers could seek to invest the monies entrusted to them in such a way as to re-

11. In the special case $W_{1 t}=W_{2 t}$, this result is equivalent to Lintner's [1969] demonstration that the market price of risk equals the harmonic mean of individual investors' diverse risk aversions.

12. See, for example, Murray [1968], Soldofsky [1971], and Drucker [1976]. 
produce the composition of the general public's directly held aggregate portfolio. At the other extreme, the general public could rearrange its directly held portfolio so as to offset any independent movements in the portfolio held for it in pension funds. If a pension fund accumulated proportionately more long-term bonds than the individuals who are its ultimate owners would have held, for example, they could simply sell off enough bonds from their private portfolios to leave their combined investment positions unaltered.

There are several reasons, however, for believing that a shift from direct wealth ownership to indirect ownership via pension funds does in fact imply a shift in portfolio preferences and hence (in general) a shift in asset yield relationships. In the first instance, individuals have more freedom to invest their directly held portfolios as they wish, in comparison with pension funds that are typically subject to a variety of restrictions imposed by federal and state-level legislation and regulatory rulings. Second, the tax deferral feature of "qualified" pension funds is likely to shift asset return preferences from fully or partially tax exempt forms (e.g., interest on municipal bonds or capital gains, respectively) toward fully taxable forms (e.g., interest on corporate bonds). Third, in practice, zero constraints appear to be an important part of the story. While in principle individuals can sell bonds to offset pension funds' purchases of bonds in their behalf, in fact few individuals hold bonds, and market arrangements make short sales difficult if not impossible in small amounts. Fourth, the familiar effects of asset pooling arrangements may be important in the pension context in several respects. Since very large pension funds account for the bulk of U.S. pension assets, on the whole pension funds face far smaller unit costs of acquiring information and engaging in transactions than do individuals, and have greater practical opportunities for diversification among imperfectly divisible assets.

Moreover, in the case of pension funds the "intermediation effects" of asset pooling go well beyond the usual increase in the stability and predictability of cash inflows and outflows associated with averaging across a large number of individuals with volatile but imperfectly related income and consumption streams. Virtually all large qualified pension plans in the United States rely on distribution systems of a contractual annuity form prohibiting lump-sum withdrawals. ${ }^{13}$ In addition to deferring compensation until retirement,

13. It is puzzling that individuals are willing to sacrifice the liquidity of their pension fund assets, while they purchase so few annuities directly. Although grouppurchase features may play some role, the terms on pension-related annuities are in fact not very much more favorable than on individually purchased annuities. Perhaps liquidity seems less important on asset claims that are already deferred until retirement. 
therefore, by participating in a pension plan workers undertake to give up the liquidity of their claims even after they become eligible to receive them. Hence in contrast to banks, which are able to "borrow short and lend long" largely by relying on the averaging of individual behavior patterns to ensure that all depositors do not simultaneously withdraw their funds, pension funds typically face long-term liability streams set by contractual arrangements and subject to short-run variations due only to varying aggregate retirement decisions and to random noise around actuarial means.

Yet an additional aspect of the effect of pension funds on aggregate portfolio preferences is that pensions may actually change the identity of savers in the sense of ultimate asset ownership as in Section I. In the case of private pension funds, most of the large plans are of the "defined benefit" form in which the employer assumes a fixed liability to the employees, and the assets in the pension fund are the property of the owners of the firm (in the sense that they, not the plan's contractual beneficiaries, stand to gain or lose according to the realized return on the fund's assets). To the extent that pension arrangements take the place of workers' direct saving, while the firm's equity holders accumulate assets to fund their resulting liabilities, the ownership of marketable assets shifts from the working public to equity holders (who are, by self-selection, probably less risk-averse). ${ }^{14}$ Similarly, in the case of state and local government pension funds, the effect is to shift the ultimate ownership of marketable assets from government workers to the taxpayers.

Finally, the need to trace private and state-local government pension fund assets back to equity holders and taxpayers, respectively, highlights the demands on information availability and investors' perspicacity that would be required by the argument that individuals rearrange their directly held portfolios so as to offset the effect of pension funds' asset selection on aggregate portfolio preferences. Here what would have to be involved would be "ultrarationality" (in the sense of David and Scadding [1974]) with respect to not merely the amount but also the composition of saving. ${ }^{15}$ In the case of private

14. Two complications arise here, however. First, whether or not pension arrangements lead the beneficiaries to reduce their private saving is a matter of current debate; see, for example, Feldstein $[1974,1978]$ and the references cited therein. Second, for both private and state-local government pensions, many employers opt for significantly less than full funding; see, for example, Munnell and Connolly [1976], Feldstein [1978], and Oldfield [1977]. Both issues lie beyond the scope of this paper.

15. It is interesting to note that David and Scadding clearly rejected the application of "ultrarationality" to intermediation effects on portfolio composition, citing (p. 247) "... the significant effects of financial intermediaries in facilitating the shifts in the composition of savings which, over the long run, have probably been essential in staving off a decline in the real rate of return on "capital." 
pension funds, nowhere in its annual report to shareholders or its $10-\mathrm{K}$ SEC filing need a corporation indicate either the aggregate value or the composition of the assets in its pension fund. ${ }^{16}$ Only by consulting that part of the unpublished Form 5500 reports that the Department of Labor requires (Form 5500 is a joint IRS-Labor filing) can a shareholder discover the relevant information; and in practice the research reports produced by the securities industry rarely refer to even the value, much less the composition, of these assets. The corresponding information for state and local government pension funds is in principle more readily available, but it strains belief to suppose that many taxpayers examine the pension fund portfolios, impute personal returns via their future tax liabilities, and readjust their directly held portfolios accordingly.

Hence, it is plausible a priori not only that pension funds may exhibit portfolio preferences which differ from those reflected in individuals' direct asset holdings, but also that individuals may not seek (or be able) to offset fully the portfolio allocations made by pension funds. How has the actual experience in recent years, during the period of pension funds' most rapid growth to date, jibed with these considerations? 'Table I shows the aggregate portfolio composition, as of yearend 1975, for households' direct holdings, for pension funds of private businesses, and for pension funds of state and local governments (including both "employees" and "teachers" funds). ${ }^{17}$ These data immediately suggest differences in asset preferences consistent with the underlying factors noted above, especially the long-term contractual nature of pension funds' liabilities. The two groups of pension funds held 93 percent and 98 percent of their respective aggregate portfolios in long-term credit market instruments (mostly corporate bonds and equities), while households held only 48 percent of their directly owned financial assets in this form and held an additional 48 percent in deposit form. ${ }^{18}$ To the extent that these actual holdings are indicative of the three groups' desired holdings as in (1), they provide evidence of sharply differing asset preferences.

16. U.S. corporations' balance sheet statements contain no reference whatsoever to pension assets or liabilities. A footnote to the balance sheet is required to report the difference between vested pension liabilities and total pension assets, but need not even indicate the two respective totals, much less the asset composition. Form 10-K need not reveal any further pension information, and most corporations do not provide more than is required.

17. Data are from the Federal Reserve System's flow-of-funds accounts. Data for the household sector, which consists primarily of individuals but also includes nonprofit organizations and bank-managed personal trusts, exclude life insurance and pension reserves. For all three sectors, the portfolio as considered here includes financial assets only; this restriction is especially important for households, who hold substantial (though difficult to measure) wealth in the form of private housing and durables. 
In a world of transactions costs, however, it is not in general valid to assume that an investor's actual holdings at any given time precisely represent the correspondi desired portfolio allocation. Shifts in yield relationships or risk assessments, in market structures or transactions arrangements, or in any of the institutional factors noted above will cause the desired allocation to change; and in the presence of transactions costs it will not be optimal to reallocate the portfolio so as to achieve the new equilibrium of desired holdings immediately. Table II shows the average annual net financial asset accumulations (flows) corresponding to the holdings (stocks) shown in Table I, for the decade through 1975 , on a price-adjusted basis. ${ }^{19}$ Here the divergence between households' and pension funds' portfolio behavior is even more pronounced. The allocation of pension funds' accumulations during this period largely matched that of their 1975 holdings. By contrast, although households held 32 percent of their directly owned financial assets in equities at yearend 1975, they were heavy net sellers of equities on average for the previous ten years. Furthermore, while households invested only about one-sixth of their direct net financial asset accumulation in all long-term credit market instruments, pension funds invested in virtually nothing else.

These starkly different investment patterns suggest that empirically estimating separate asset demand equations of the form (1), for households and for pension funds, would yield different values for $B_{t}$ and $\pi_{t}$ for the three sectors in each time period. Following the analysis in Section I, therefore, it appears as if shifting the pattern of wealth ownership away from households toward pension funds would on balance increase the demand for long-term (i.e., more risky ${ }^{20}$ ) assets and thereby reduce the relative yields on these assets. In the Lintner-Sharpe context this redistribution would reduce the average market price of risk over time. In the Operation Twist context it would reduce the average slope of the term-structure yield curve over time.

18. Because of the volatility of equity prices, these percentages and the others shown in Table I differ markedly from one yearend to the next. Households' equity holdings measured at market value totaled as much as $\$ 929$ billion at yearend 1972 and as little as $\$ 477$ billion at yearend 1974 , for example, and pension funds' holdings varied analogously. The principal difference noted in the text, however, remains valid regardless of the arbitrary reference point chosen.

19. Accumulations of equities shown in Table II are net of market price changes and therefore reflect only the differences between total purchases and total sales.

20. Although it is customary to consider long-term assets more risky than shortterm assets because of the greater "capital risk" associated with their greater price volatility, it should be clear from the discussion above that long-term assets may actually be safer for investors (like pension funds) for whom "income risk" is more important. For a useful discussion of this point, see Stiglitz [1970]. 


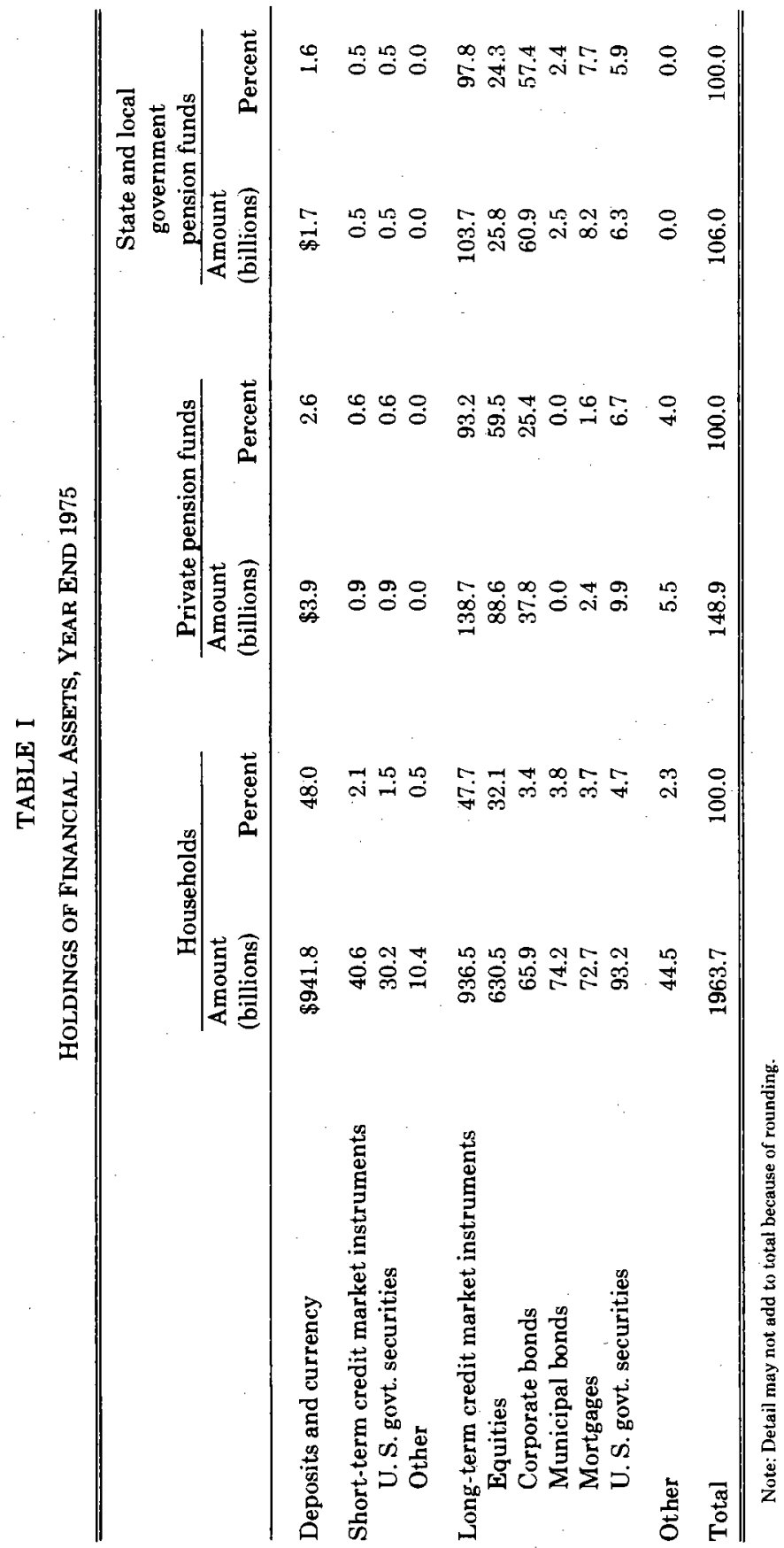




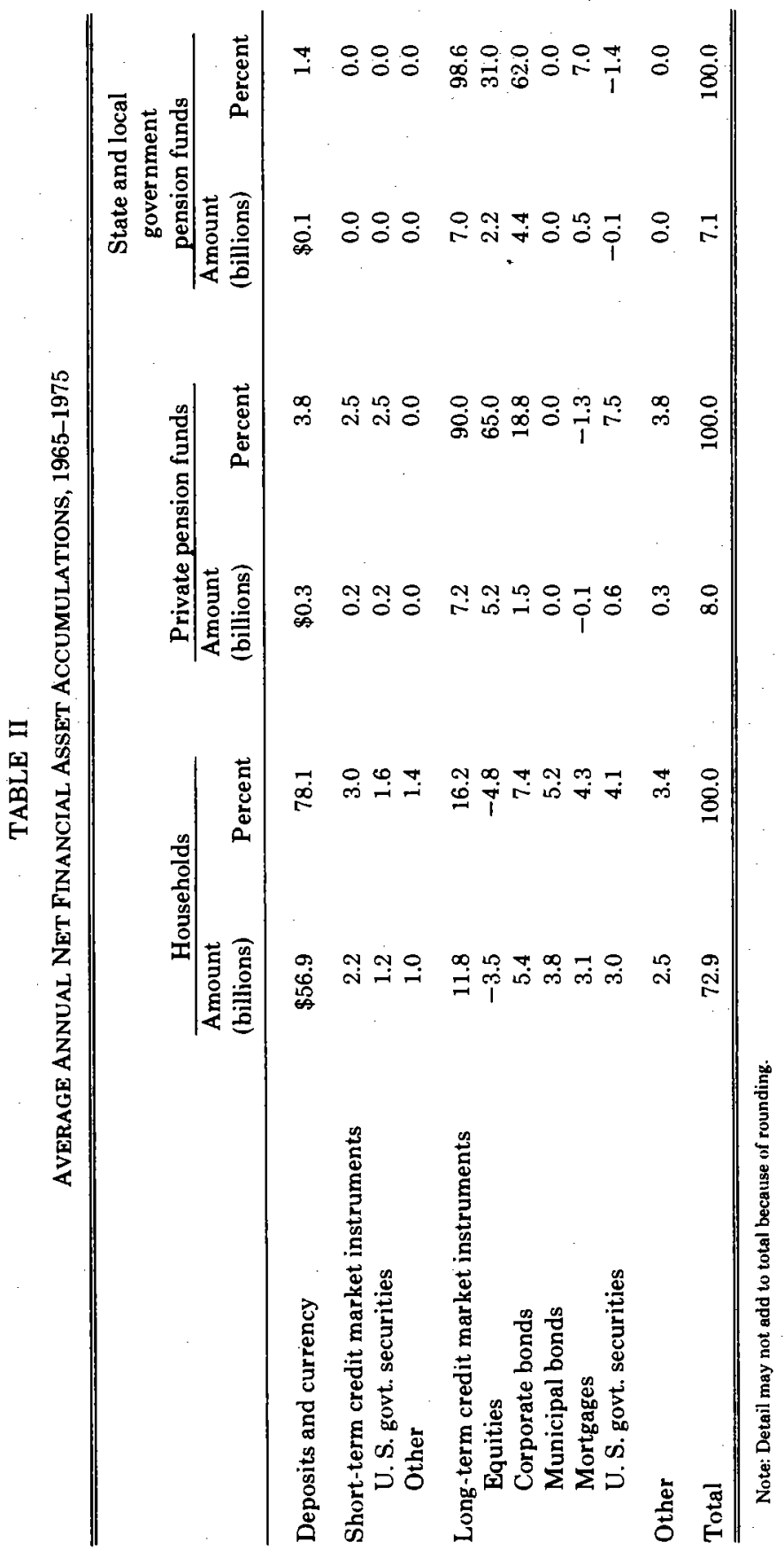


Since (1) includes several unobservable variables, however, it is necessary to impose further assumptions so as to render these asset demand statements operational. Friedman $[1977,1980]$ and Friedman and Roley [1979] applied different sets of assumptions for this purpose and presented estimates for the equation in (1) corresponding to each sector's net demand for long-term corporate bonds-the asset most closely associated with the literature on the term structure of interest rates. ${ }^{21}$

First, since the expected holding-period yields $\mathbf{r}_{t}^{e}$ in (1) are unobservable, some proxy is necessary for purposes of estimation. In Friedman [1977] these unobservable expected yields were simply replaced by observed actual yields (including yields to maturity for bonds), and several subsidiary variables were included to proxy expectations effects. In Friedman [1980] and Friedman and Roley [1979], expected holding-period yields were explicitly modeled as generalized autoregressive expectations (sometimes called "partly rational" or "weak-form rational" expectations) based on observed prior capital gains and losses, etc. ${ }^{22}$

Second, the Jacobian $B_{t}$ and vector $\pi_{t}$ in (1) are functions of the perceived risk structure $\Omega_{t}$, which is also unobservable. In Friedman [1977] and Friedman and Roley [1979], $\Omega_{t}$ was assumed to be constant for all $t$, so that $B_{t}$ and $\pi_{t}$ become constant parameters $B$ and $\pi$, respectively. In Friedman [1980] $\Omega_{t}$ was explicitly modeled as a moving-average function of the prior variation in observed holding-period yields, and (1) was linearized with respect to $\Omega_{t}$, so that separate (constant) parameters apply to the elements of both $\mathbf{r}_{t}^{e}$ and $\Omega_{t}$.

Third, in the presence of transactions costs, an investor never fully implements the desired allocation $\alpha_{t}^{*}$ from (1), so that it too is unobservable. As is commonplace in such situations, Friedman [1977, 1980] and Friedman and Roley [1979] used a model of portfolio adjustment to translate the desired portfolio allocation implications of (1) into an operational model of the investor's behavior. The "optimal marginal adjustment" model, on which all three of these sets of estimates relied, is useful for this purpose in that it generalizes the familiar stock adjustment model by explicitly relating the investor's short-run portfolio adjustments not only to the discrepancies $\left(\mathbf{A}_{t}^{*}-\right.$

21. Until recently the U.S. Treasury was unable to issue bonds bearing coupons greater than $4 \frac{1}{4}$ percent. For most of the relevant sample period, therefore, no new issues of long-term Treasury securities existed, and yields on the outstanding issues incorporated the familiar "coupon bias" (see, for example, Modigliani and Shiller
[1979]).

22. In addition, both papers presented estimates based on rational expectations proxies, but these estimates were largely unsuccessful. 
$A_{t-1}$ ) between the desired asset holdings indicated by (1) and the corresponding previous-period holdings but also to the current investable cash flow. The primary rationale for distinguishing the cash flow in this context is that current cash flows are typically more easily (i.e., costlessly) allocated than are existing asset holdings. Since transactions costs constitute, in the first instance, the underlying motivation for using a model that admits discrepancies between actual and desired portfolio holdings, ${ }^{23}$ it is worthwhile to model the implications of transactions costs with some care. The optimal marginal adjustment model is an approximation that incorporates in a tractable form the differential transactions costs between the investor's allocation of a new cash flow and the reallocation of existing asset holdings by positing the allocation of the current cash flow according to whatever proportions (1) indicates are desired for the total portfolio; specifically, given an investor's beginning-of-period wealth and current-period cash flow, ${ }^{24}$

$$
\Delta \mathbf{A}_{t}=\theta\left(W_{t-1} \alpha_{t}^{*}-\mathbf{A}_{t-1}\right)+\Delta W_{t} \alpha_{t}^{*},
$$

where the equilibrium allocations $\alpha_{t}^{*}$ follow from (1) and $\theta$ is a matrix of adjustment coefficients that, from the relevant "adding-up" constraint, must exhibit identical column sums.

Since the optimal marginal adjustment model's primary advantage is that it captures the easier short-run "transactability" of the investor's new cash flow $\Delta W_{t}$ in comparison with existing assets $W_{t-1}$, as suggested empirically by the contrast between Tables I and II, it indicates that in the short run a shift of wealth ownership from one sector to another can have a major impact on the structure of market yields even if it is small in comparison with the different sectors' total asset holdings-as long as it is large in comparison with their typical respective cash flows. For transfers from households to pension funds in the United States, this implication is potentially very important. The average annual ratio of net financial asset accumulation to beginning-of-period wealth, for the decade included in Table II, was 0.045 for households, 0.075 for private pension funds, and 0.117 for state and local government pension funds.

Expansion of (9) with (1) substituted for $\alpha_{t}^{*}$ shows that the

23. See Foley [1975] for a useful analysis of this issue.

24. Here $W_{t-1}$ differs from the $W_{t}$ in Section $I$, in that it excludes the new cash inflow $\Delta W_{t}$. Heuristically, the first term on the right-hand side of (9) represents the reallocation, according to a standard multivariate stock-adjustment model, of the investor's existing asset holdings $\mathbf{A}_{t-1}$ (which satisfy $\mathbf{A}_{t-1^{\prime}}=W_{t-1}$ ), while the second term represents the allocation of the investor's current-period cash flow $\Delta W_{t}$ according to the equilibrium proportions $\boldsymbol{\alpha}_{t}^{*}$ (which satisfy $\boldsymbol{\alpha}_{t}^{\prime \prime} 1=1$ ). 
TABLE III

Estimates OF Bond Demand Responsiveness to Bond Yields

\begin{tabular}{lccc}
\hline \multicolumn{1}{c}{ Estimate } & Households & $\begin{array}{c}\text { Private } \\
\text { pension } \\
\text { funds }\end{array}$ & $\begin{array}{c}\text { State and local } \\
\text { government } \\
\text { pension funds }\end{array}$ \\
\hline Friedman [1977] & $0.032(4.4)$ & $0.155(6.5)$ & $0.099(4.7)$ \\
Friedman [1980] & $.077(5.1)$ & $.100(3.1)$ & $.077(2.0)$ \\
Friedman and Roley [1979] & $.124(5.2)$ & $.069(5.9)$ & $.209(4.5)$ \\
Mean of the three estimates & .075 & .108 & .128 \\
\hline \hline
\end{tabular}

Note: Numbers in parentheses are ratios of estimates to standard errors.

combined operational model of desired portfolio allocation and portfolio adjustment provides direct estimates of the elements of the key Jacobian $B$ (on the assumption that they are constant) as the coefficients of single right-hand-side regressors. Hence estimation of such equations indicates the way in which different groups of investors not only exhibit distinct portfolio preferences for any given structure of asset yields but also change their portfolio preferences in distinct ways as asset yields change. ${ }^{25}$ Table III presents the estimates (together with their standard error ratios ${ }^{26}$ ) for the on-diagonal element of $B$ corresponding to the own-yield in the demand for long-term bonds, for households and the two categories of pension funds, from the three papers cited above. Although the estimates are somewhat irregular, on the whole they do support the further inference that pension funds' preferences for holding long-term bonds are systematically more sensitive to bond yields than are households' preferences for bonds.

\section{INTEREST RATE EFFECTS OF TRANSFERS FROM HOUSEHOLDS TO PENSION FuNDS}

The analysis in Section I, together with the empirical evidence presented in Section II, suggests that increasing the asset accumulation which individuals do through pension funds while correspondingly reducing the asset accumulation which individuals do

25. It is impossible to infer such information from simple inspection of data such as those in Tables I and II.

26. Because the equations were in each case estimated using an instrumentalvariables procedure (to allow for the simultaneity between yield and demand), these ratios are asymptotically distributed as $t$-statistics but are not necessarily distributed as $t$-statistics in small samples. 
TABLE IV

TeRm STRUCTURE Simulations, 1967-1973

\begin{tabular}{lcc}
\hline \hline & \multicolumn{2}{c}{ Long-short yield spread } \\
\cline { 2 - 3 } & $\begin{array}{c}1967-1973 \\
\text { Average }\end{array}$ & $\begin{array}{c}\text { Difference } \\
\text { from control }\end{array}$ \\
\hline Actual & $1.10 \%$ & $0.02 \%$ \\
Control simulation & 1.12 & - \\
$\$ 10$ billion saving shift & 0.75 & 0.37 \\
$\$ 25$ billion saving shift & 0.20 & 0.92 \\
$\$ 10$ billion saving increase & 0.72 & 0.40 \\
$\$ 25$ billion saving increase & 0.13 & 0.99 \\
\hline \hline
\end{tabular}

Note: First four lines correspond to plots in Figure I; saving increase simulations not plotted.

directly would reduce the average slope of the term-structure yield curve. What magnitude effect would be likely to follow from such a rechanneling of saving in reasonable magnitudes?

Table IV and Figure I summarize the results of partial-equilibrium experiments based on the bond demand equations estimated in Friedman [1977] for six categories of bond investors and the bond supply equations estimated in Friedman [1979] for two categories of

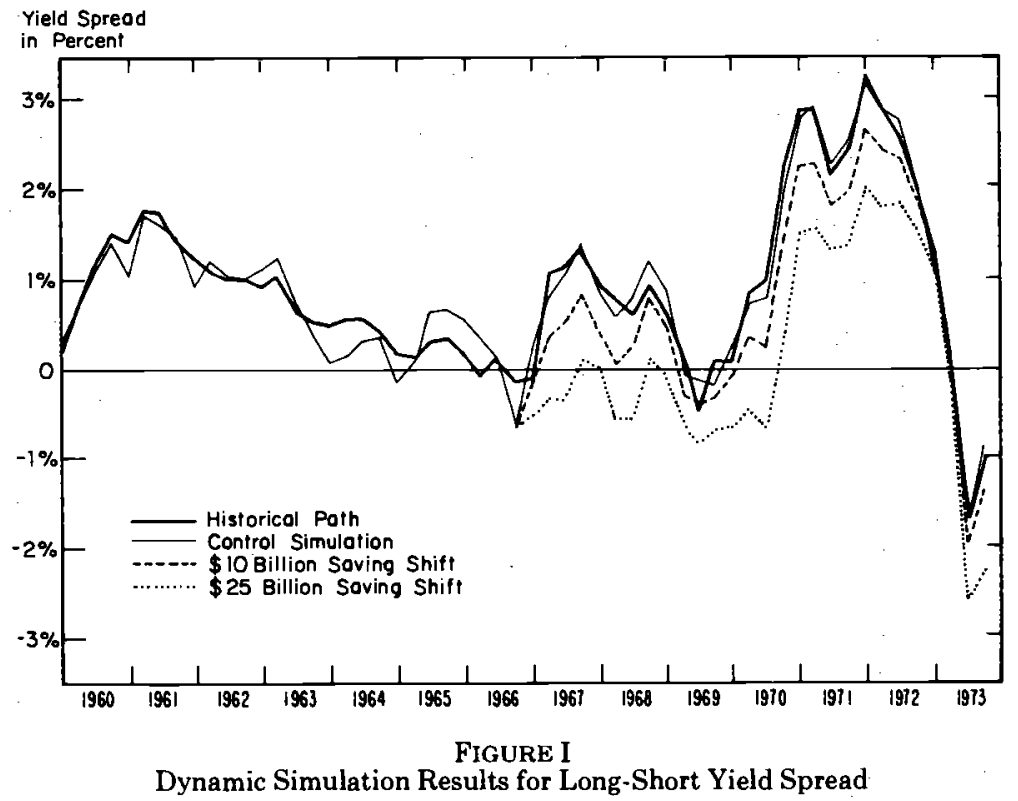


bond issuers, using quarterly U. S. data for 1960:I-1973:IV. ${ }^{27}$ Following (6), combining these eight equations with a market-clearing equilibrium condition provides a nine-equation model that (for given values of wealth endowments, cash flows, and yields on other assets) determines the eight bond quantities and the own-yield on bonds. The experiments considered here assess the term-structure effect of shifting wealth ownership from households to pension funds by using this model to simulate the value of the long-term bond yield under different sets of assumptions about wealth distributions, while holding fixed all other variables (including, in particular, short-term interest rates).

It is important to note at the outset that, since these experiments hold a great many variables fixed-for example, there are no feedbacks from nonfinancial economic activity-they are, like (6), only a partial-equilibrium account of the determination of the structure of asset yields. If monetary policy acts to hold short-term yields fixed while the pattern of wealth ownership shifts, for example, then effects on the term structure will translate directly into effects on long-term yields that presumably either stimulate or retard saving and investment. Alternatively, if monetary policy holds money stock growth fixed while wealth ownership shifts, then both short- and long-term yields will presumably change, and nonfinancial economic activity will respond in yet different ways. Hence a complete general equilibrium analysis, using a comprehensive model of all asset markets and all nonfinancial markets, would in general give somewhat different estimates. Such a large-scale analysis lies beyond the scope of this paper. Since the starting point of the analysis is the asset markets, however, a partial-equilibrium analysis of term-structure effects is instructive nonetheless. ${ }^{28}$

The heavy solid line in Figure I plots the observed historical values of the difference between long- and short-term interest rates, as measured by the Aa utility new-issue yield and the 4-6 month prime commercial paper yield, respectively, over the 1960-1973

27. The bond investors include life insurance companies, other insurance companies, private pension funds, state and local government pension funds, mutual savings banks, and households; as of yearend 1975 these six groups held 95 percent of all corporate bonds issued in the United States. The bond issuers include domestic nonfinancial corporate businesses and finance companies; as of yearend 1975 these two groups accounted for 90 percent of all corporate bonds issued in the United States. See Friedman $[1977,1979]$ for details of the estimation procedure and for a complete listing. of the eight equations.

28. In fact, most of the literature of asset market behavior in general and interest rate behavior in particular, at both the theoretical and the empirical levels, has adopted such a partial-equilibrium approach. See, for example, the references cited in Section I. 
sample period used in estimating the eight bond demand and supply equations. The yield curve slope, as measured here, varied substantially during these years. Long-term yields usually exceeded shortterm yields, and the greatest spread between the two emerged during the economic recoveries of 1961-1962 and 1971-1972. During several episodes of restrictive monetary policy, however, short-term yields exceeded long-term yields. As Table IV shows, the mean long-short yield spread during 1967-1973 (the second half of the sample period) was 1.10 percent (i.e., 110 basis points).

The light solid line in Figure I plots the corresponding values of this yield spread produced by a "control" simulation of the nineequation bond market model using historical values of all exogenous variables (including the short-term yield). The control simulation is fully dynamic in that, after the first quarter of the simulation, the solution uses internally generated values for the lagged stocks of bonds either held or issued by each of the eight groups of bond investors and issuers, as well as for the series of lagged own-yields on bonds (which plays an important role in determining expectations of holding-period yields in some of these equations).

This control simulation indicates that the nine-equation partial equilibrium model of the long-term bond market reproduces the relevant historical experience with reasonable accuracy. There is no significant bias for any of the model's nine jointly determined variables, and the mean simulated value of the long-short yield spread is (to two decimal places) identical to the historical mean. For the eight bond demand and supply variables, the root-mean-square simulation errors are about in line with those of the respective estimated equations, indicating that the errors made by individual equations have no observable tendency to compound one another. For the termstructure spread itself, the root-mean-square error is 0.21 percent (i.e., 21 basis points) —about comparable to the "fit" achieved by previous researchers who have directly estimated reduced-form equations for long-term interest rates given the path of short-term interest rates. ${ }^{29}$ This within-sample performance seems quite creditable, especially since the structural modeling methodology applied here does not

29. For example, Modigliani and Shiller's [1973] preferred equation had $S E=$ 0.13 percent for the less volatile Aaa yield (again given the short-term yield) over the sample period 1955:III-1971:II, but reestimating the equation using the Aa yield and the 1960:I-1973:IV sample period leads to $S E=0.22$ percent. Similarly, Feldstein and Eckstein's [1970] preferred equation (which excluded the short-term yield) had $S E$ $=0.09$ percent for the Aaa yield over the sample period 1954:I-1969:II, but reestimating the equation using the Aa yield and the 1960:I-1973:IV sample period leads to $S E=$ 0.29 percent. 
estimate an equation directly for either the long-term yield or the long-short spread but, instead, implies an equation for the long-term yield (given the short-term yield) that is restricted by the underlying structural hypotheses about bond investors' and bond issuers' portfolio behavior ${ }^{30}$ As Table IV shows, the simulated mean long-short yield spread during 1967-1973 is 1.12 percent, practically identical to the historical mean.

What effect on the term structure will follow due to a shift away from direct individual saving toward saving via pension funds? The broken line in Figure I plots the values of the long-short yield spread from a second simulation which differs from the control in that annual asset accumulation in the amount of $\$ 10$ billion is shifted from households to pensions funds during the second half of the simulation period (1967-1973). ${ }^{31}$ This simulation therefore directly corresponds to the analysis in Section I in that, in comparison with the control, it assumes a shift in the distribution of wealth holding without any change in the total. As the data in Section II suggest, this redistribution toward investors with preferences for long-term assets sharply reduces long- relative to short-term yields. Table IV summarizes this effect, showing that the average long-short yield spread during $1967-1973$, after the $\$ 10$ billion redistribution, is 0.75 percent -0.37 percent less than in the control simulation. An analogous annual redistribution in the amount of $\$ 25$ billion, indicated by the dotted line in Figure I, leads to a similar but even larger effect, almost entirely eliminating the average upward slope of the yield curve. As Table IV shows, the average long-short yield spread during 1967-1973, after the $\$ 25$ billion redistribution, is only 0.20 percent- 0.92 percent less than in the control simulation.

Since the question of individuals' saving response to the level of pension contributions is currently the object of much research, ${ }^{32}$ it is useful to consider alternatives to the extreme assumption, under-

30. This point is especially relevant to the presence of other long-term yields in the estimated bond demand equations for several categories of investors. Including other long-term yields as independent variables in an unrestricted equation with the bond yield as dependent variable would presumably increase greatly such an equation's fit. In the context of the structural model, however, the contribution of other long-term yields is restricted to their role in influencing the net purchases variables. See Friedman [1977] and Friedman and Roley [1977] for a discussion of the structural modeling methodology as specifically applied to the determination of long-term interest rates.

31. Specifically, the asset accumulation is shifted entirely to state and local government pension funds. Recent pension legislation (especially the 1974 Act) suggests that, in the future, private pension funds' portfolio preferences may come to resemble the pattern reflected in recent years by state and local government pension funds.

32. See again Feldstein $[1974,1978]$. 
lying the two simulation experiments plotted in Figure I, that the reduction in individuals' direct saving exactly matches the increase in pension accumulations, thereby leaving the total of their direct and indirect saving unchanged. For purposes of comparison, therefore, Table IV also indicates the results of two further simulations that adopt the opposite extreme assumption-i.e., that individuals do not reduce their direct saving at all in response to increased pension contributions. These simulations represent annual increases of either $\$ 10$ billion or $\$ 25$ billion in total financial asset accumulation, with all of the increase going to pension funds. As Table IV shows, the flattening of the term structure associated with these pension-oriented saving increases is slightly greater than the corresponding effects due to a redistribution toward pension funds with no increase in total saving. Nevertheless, as indicated above, the partial-equilibrium nature of these experiments is not adequate to assess the full implications of a change in the volume of total saving. For example, if individuals save more via pensions yet save no less directly, they must consume less, and hence the overall level of economic activity and income must change; but these simulations take income as given. Similarly, if total saving rises, investment must rise also; but, while these simulations allow for corporations' shifting toward bond financing as the yield curve flattens, they take as given firms' investment expenditures and external deficits. Both of these problems arise immediately in the case of the "saving increase" simulations but not the "saving shift" simulations that are more directly in the spirit of the analysis in Section I.

Even the pure "saving shift" experiments reported here are subject to some qualification because of the partial-equilibrium nature of the analysis, so that these simulations clearly do not provide the last word on the term-structure effects of redistributions from individuals to pension funds. Moreover, following the discussion in Section II, the estimated effects reported in Table IV represent a form of upper bound in that they assume that households do no rearranging of their directly held assets to offset the asset selections made by pension funds. Nevertheless, two conclusions stand out strongly from this empirical analysis. First, the estimated model of the long-term bond market does imply, as both theoretical analysis and other a priori considerations suggest, that a shift in the form of wealth ownership leads to a corresponding shift in the structure of asset yields. Second, such wealth redistributions in plausible magnitude can lead to major shifts in asset yields in comparison with historical relationships. 


\section{SUMMARY OF CONCLUSIONS}

Although economists have most often considered influencing the structure of asset yields by altering relative asset supplies, in a world of heterogeneous investors equivalent effects may also follow from redistributions among wealth holders, or among forms of wealth holding, exhibiting different portfolio preferences. A redistribution in favor of less risk-averse investors, for example, reduces the premium that the market in aggregate associates with risky assets. A redistribution in favor of investors who typically prefer long-term assets reduces the slope of the term-structure yield curve.

Empirical evidence for the United States shows that pension funds exhibit portfolio preferences that are markedly different from those of individuals. Pension funds hold far greater shares of their total financial assets in long-term instruments than do individuals, and the difference in their respective allocations of new cash flows is even more pronounced. Econometric evidence also indicates that pension funds' portfolio behavior is more interest-sensitive in this regard than is individuals' behavior.

Partial-equilibrium simulation experiments based on a model of the U.S. long-term bond market indicate that redistributions of saving flows from individuals to pension funds, in plausible magnitudes, can have major effects on the term structure of interest rates. A change in this direction from the historical pattern of saving during $1967-1973$, in the amount of either $\$ 10$ billion or $\$ 25$ billion annually, would have reduced the average slope of the yield curve from the historical 1.12 percent to 0.75 percent or to 0.20 percent, respectively. Such shifts in the term structure are substantial in comparison to those discussed in the context of the "Operation Twist" surrogate debt management effort of the early 1960s, and they would probably be sufficient to have major implications for nonfinancial economic activity.

HARVARD UNIVERSITY

\section{REFERENCES}

Arrow, Kenneth J., Essays in the Theory of Risk Bearing (Amsterdam: North-Holland Publishing Company, 1970).

Borch, K., "A Note on Uncertainty and Indifference Curves," Review of Economic Studies, XXXVI (Jan. 1969), 1-4.

Bosworth, Barry, and James S. Duesenberry, "A Flow of Funds Model and Its Implications," Issues in Federal Debt Management (Boston: Federal Reserve Bank of Boston, 1973). 
Brainard, William C., and James Tobin, "Pitfalls in Financial Model-Building," American Economic Review, LVIII (May 1968), 99-122.

David, Paul A., and John L. Scadding, "Private Savings: Ultrarationality, Aggregation, and 'Denison's Law,' "Journal of Political Economy, LXXXII (March/April 1974), 225-49.

DeLeeuw, Frank, "A Model of Financial Behavior." Duesenberry et al., eds., The Brookings Quarterly Econometric Model of the United States (Chicago: Rand McNally \& Company, 1965).

Drucker, Peter F., How Socialism Came to America (New York: Harper \& Row, 1976).

Fama, Eugene F., "Multiperiod Consumption-Investment Decisions," American Economic Review, LX (March 1970), 163-74.

Feldstein, Martin S., "Mean-Variance Analysis in the Theory of Liquidity Preference and Portfolio Selection," Review of Economic Studies, XXXVI (Jan. 1969), $5-12$.

-—, "Social Security, Induced Retirement and Aggregate Capital Accumulation," Journal of Political Economy, LXXXII (Sept./Oct. 1974), 905-26.

- , "The Social Security Fund and National Capital Accumulation," Funding Pensions: Issues and Implications for Financial Markets (Boston: Federal Reserve Bank of Boston, 1976).

_- "Do Private Pensions Increase National Saving?" Journal of Public Economics, $X$ (Dec. 1978), 277-93.

- , and Otto Eckstein, "The Fundamental Determinants of the Interest Rate," Review of Economics and Statistics, LII (Nov. 1970), 363-75.

Foley, Duncan K., "On Two Specifications of Asset Equilibrium in Macroeconomic Models," Journal of Political Economy, LXXXIII (April 1975), 303-24.

Friedman, Benjamin M., "Public Pension Funding and U. S. Capital Formation: A Medium-Run View," Funding Pensions: Issues and Implications for Capital Markets (Boston: Federal Reserve Bank of Boston, 1976).

"Financial Flow Variables and the Short-Run Determination of Long-Term Interest Rates," Journal of Political Economy, LXXXV (Aug. 1977), 661-89.

-_, "Crowding Out or Crowding In? The Economic Consequences of Financing Government Deficits,"·Brookings Papers on Economic Activity, No. 3 (1978), 593-641.

, "Price Inflation, Portfolio Choice, and Nominal Interest Rates," American Economic Review, LXX (March 1980), 32-80.

- - "Substitution and Expectation Effects on Long-Term Borrowing Behavior and Long-Term Interest Rates," Journal of Money, Credit and Banking, XI (May 1979), 131-50.

- - , and V. Vance Roley, "Structural Models of Interest Rate Determination and Portfolio Behavior in the Corporate and Government Bond Markets," American Statistical Association, Proceedings of the Business and Economic Statistics Section (1977), 142-51.

- and Interest Rate Expectations: Unitary, Rational or Autoregressive," Econometrica, XLVII (Nov. 1979), 1475-97.

Friedman, Milton, "The Quantity Theory of Money: A Restatement," Friedman, ed., Studies in the Quantity Theory of Money (Chicago: University of Chicago Press,
1956).

Friend, Irwin, and Marshall E. Blume, "The Demand for Risky Assets," American Economic Review, LXV (Dec. 1975), 900-22.

Hendershott, Patric H., Understanding Capital Markets Volume I: A Flow-of-Funds Model (Lexington: D. C. Heath \& Company, 1977).

Hicks, J. R., "Liquidity," Economic Journal, LXXII (Dec. 1962), 671-709.

Lintner, John, "The Valuation of Risky Assets and the Selection of Risky Investments in Stock Portfolios and Capital Budgets," Review of Economics and Statistics, XLVII (Feb. 1965), 13-37.

—_, "The Aggregation of Investor's Diverse Judgments and Preferences in Purely Competitive Security Markets," Journal of Financial and Quantitative Analysis, IV (Dec. 1969), 347-400.

Markowitz, Harry, "Portfolio Selection," Journal of Finance, VII (March 1952), 77-91. 
Merton, Robert C., "Lifetime Portfolio Selection Under Uncertainty: The Continuous-Time Case," Review of Economics and Statistics, LI (Aug. 1969), 247-57.

Modigliani, Franco, and Robert J. Shiller, "Inflation, Rational Expectations, and the Term Structure of Interest Rates," Economica, XL (Feb. 1973), 12-43.

Measurement of the Cost of Debt Capital," Journal of Financial Economics, VII (Sept. 1979), 297-318.

Modigliani, Franco, and Richard Sutch, "Innovations in Interest Rate Policy,"

- - , and - - "Debt Management and the Term Structure of Interest Rates: An Empirical Analysis of Recent Experience," Journal of Political Economy, LXXV (Aug. 1967), 569-89.

Mossin, Jan, "Optimal Multiperiod Portfolio Policies," Journal of Business, XLI (April 1968), 215-29.

Munnell, Alicia H., and Ann M. Connolly, "Funding Government Pensions: StateLocal, Civil Service and Military," Funding Pensions: Issues and Implications for Financial Markets (Boston: Federal Reserve Bank of Boston, 1976).

Murray, Roger F., Economic Aspects of Pensions: A Summary Report (New York: National Bureau of Economic Research, 1968).

Oldfield, George S., "Financial Aspects of the Private Pension System," Journal of Money, Credit and Banking, IX (Feb. 1977), 48-54.

Patinkin, Don, Money, Interest, and Prices, 2nd ed. (New York: Harper \& Row, 1965).

Roley, V. Vance, "A Structural Model of the U. S. Government Securities Market," Ph.D. thesis, Harvard University, 1977.

_-_, "A Theory of Federal Debt Management," American Economic Review, LXIX (Dec. 1979), 915-26.

Samuelson, Paul A., "Lifetime Portfolio Selection by Dynamic Stochastic Programming," Review of Economics and Statistics, LI (Aug. 1969), 239-46.

-.-."The Fundamental Approximation Theorem of Portfolio Analysis in Terms of Means, Variances, and Higher Moments," Review of Economic Studies, XXXVI] (Oct. 1970), 537-42.

Sharpe, William F." "Capital Asset Prices: A Theory of Market Equilibrium Ünder Conditions of Risk," Journal of Finance, XIX (Sept. 1964), 425-42.

Soldofsky, Robert M., Institutional Holdings of Common Stock 1900-2000 (Ann Arbor: University of Michigan, Graduate School of Business Administration, Bureau of Business Research, 1971).

Stiglitz, J. E., "A Consumption-Oriented Theory of the Demand for Financial Assets and the Term Structure of Interest Rates," Review of Economic Studies, XXXVII (July 1970), 321-51.

Tobin, James, "Liquidity Preference as Behavior Toward Risk," Review of Economic Studies, XXV (Feb. 1958), 65-86.

_- "An Essay on the Principles of Debt Management," Commission on Money and Credit, Fiscal and Debt Management Policies (Englewood Cliffs: Prentice-Hall, Inc., 1963).

-_, "A General Equilibrium Approach to Monetary Theory," Journal of Money, Credit and Banking, I (Feb. 1969), 15-29.

Tsiang, S. C., "The Rationale of the Mean-Standard Deviation Analysis, Skewness Preference, and the Demand for Money," American Economic Review, LXII (June 1972), 354-71. 